\title{
Chapter 14 \\ Review of Policy Instruments for Climate-Smart Mountain Forestry
}

\section{Lenka Dubova, Lenka Slavikova, João C. Azevedo, Johan Barstad, Paola Gatto, Jerzy Lesinski, Davide Pettenella, and Roar Stokken}

\begin{abstract}
Implementing the Climate-Smart Forestry (CSF) concept into practice requires interaction among key stakeholders, especially forest owners and managers, policymakers (or regulators in general), forest consultants, and forest users. But what could be the most effective policy instruments to achieve climate smartness in mountain forests? Which ones would be the most acceptable for forest owners? And for the local forest communities? Should they be designed and implemented with the use of participatory approaches or rather on a top-down basis? This chapter summarizes key policy instruments structured in three subsequent categories: commandand-control, voluntary market-based instruments, and community cooperation. It provides examples of their functioning in the forestry sector and discusses their suitability for the implementation of climate smart forestry. It appears that there are
\end{abstract}

L. Dubova $(\triangle) \cdot$ L. Slavikova

Institute for Economic and Environmental Policy, Faculty of Social and Economic Studies

J. E. Purkyne University, Usti nad Labem, Czech Republic

e-mail: lenka.dubova@ujep.cz; lenka.slavikova@ujep.cz

J. C. Azevedo

Instituto Politécnico de Bragança, Escola Superior Agrária, Campus de Santa Apolónia,

Bragança, Portugal

e-mail: jazevedo@ipb.pt

J. Barstad

University College for Green Development, Bryne, Norway

e-mail: johan@hgut.no

P. Gatto · D. Pettenella

Dipartimento Territorio e Sistemi Agroforestali, Università degli Studi di Padova, Agripolis, Padova, Italy

e-mail: paola.gatto@unipd.it; davide.pettenella@unipd.it

J. Lesinski

Department of Forest Biodiversity, Institute of Forest Ecology and Silviculture, University of Agriculture, Krakow, Poland

e-mail: jerzy.lesinski@urk.edu.pl

R. Stokken

Volda University College, Department for Social Sciences and History, Volda, Norway

e-mail: roar.stokken@hivolda.no 
many policy instruments used with varying degrees of success such as forest concessions or voluntary certification schemes. A wide range of instruments are responding to direct regulation; this has been seen as insufficient to deal with natural hazards and calamities.

\section{Abbreviations}

$\begin{array}{ll}\text { CAP } & \text { Common Agricultural Policy } \\ \text { CSF } & \text { Climate-Smart Forestry } \\ \text { CFT } & \text { Forest Territory Charters } \\ \text { CoIN } & \text { Collaborative Innovation Networks } \\ \text { CSR } & \text { Corporate social responsibility } \\ \text { EC } & \text { European Commission } \\ \text { ES } & \text { Ecosystem Service } \\ \text { EU } & \text { European Union } \\ \text { FNCoFor } & \text { Forest-owning Communes represented by their Federation } \\ \text { FOA } & \text { Forest Owners' Association } \\ \text { FSC } ® & \text { the Forest Stewardship Council } \\ \text { MF } & \text { Model Forest } \\ \text { NFO } & \text { National Forest Office } \\ \text { NGO } & \text { Nongovernmental Organization } \\ \text { NPG } & \text { New Public Governance } \\ \text { NPM } & \text { New Public Management } \\ \text { PAM } & \text { Public Administration and Management } \\ \text { PEFCTM } & \text { the Programme for the Endorsement of Forest Certification } \\ \text { PES } & \text { Payment for Ecosystem Services } \\ \text { RESP } & \text { Rural Environment Protection Scheme } \\ \text { RRI } & \text { Responsible Research and Innovation } \\ \text { SFM } & \text { Sustainable Forest Management } \\ \text { TPA } & \text { Traditional Public Administration }\end{array}$

\subsection{Introduction}

It is generally assumed that sustainable forest management (SFM) can play a significant role in climate change mitigation (e.g., Makundi 1997; FAO 2018). Moreover, according to the analysis of diverse services schemes (e.g., payments for watershed), different types of novel institutional setups based on the establishment of financial incentives to natural resources owners or managers for ecosystem service (ES) provision provide co-benefits, such as carbon mitigation and others (UNECE and FAO 2018). In accordance with Climate-Smart Forestry (CSF) (see Chap. 2 of this book: Weatherall et al. 2021), this chapter presents and describes 
tools for achieving SFM and the provision of different types of forest ES, including (but not exclusively) carbon mitigation.

According to existing institutional economics and governance structures (e.g., Thompson 2003; Lemos and Agrawal 2006; Vatn 2010; Muradian and Rival 2012; UNECE and FAO 2018), environmental governance instruments can be divided into 3 main types: 1) hierarchies (governmental command-and-control), 2) market-based (voluntary exchange), and 3) community-based (cooperation networks). Currently and most typically, these can be combined into hybrid systems (Muradian and Rival 2012; Pahl-Wostl 2019).

One possible way of categorizing these systems is through the identification of key characteristics or dimensions. Pahl-Wostl (2019) highlights the role of government, divided into three types: 1) setting the rules, 2) being a partner to society, 3) delivering services to society. Such a classification could be viewed as being consistent with the distinguishing between top-down or bottom-up approaches (e.g., Hollberg et al. 2019) or with the distinguishing of motivation: external, as based on political targets (e.g., Braune and Wittstock 2011) or internally self-motivated. The same holds for the distinguishing among the subjects: individual providers of ES, local communities, regions (local government), or the state.

While these aspects are important when economists describe how the state governs resources of economic nature, political scientists attend to how the state relates to and interacts with the citizens. Within this tradition (e.g., Bryson et al. 2014; Torfing 2018; Amdam 2020; Sørensen 2020), the public sector is often portrayed on the basis of Osborne $(2006,2010)$ and thus depicted through three different regimes: Traditional Public Administration (TPA), New Public Management (NPM), and New Public Governance (NPG). Relating to the characteristics used within the economic domain, these three regimes represent "archetypes," which often coexist or overlap, also with economic means and instruments, within Public Administration and Management (PAM).

Within TPA, the role of the state is to be a unitary and hierarchical organization, focusing upon the policy system, emphasizing policy implementation and understanding nonpublic partners as potential elements or disturbances in the policy system. Due to the hierarchical logic of this regime, citizens are framed as someone who ought to obey the state. This regime is often understood as bureaucratic in the negative sense of the word (Amdam 2020). Since citizens ought to obey the state, this regime is aligned with the "setting rules" approach described by PahlWostl (2019).

Further, NPM can be understood as a reaction to TPA and, as such, reflects a wish to modernize the public sector. Within NPM, the state is understood as a disaggregated organization with efficacy resting upon competition and market-place mechanisms. The focus is upon intraorganizational management and emphasis is on service inputs and outputs. Nonpublic partners are thus understood as independent contractors within the competitive market. In line with the private sector analogy, citizens are generally framed as customers with the ability to choose. This regime is often criticized for entailing fragmentation of power and responsibility (Amdam 
2020). Due to the role of the state as being a service provider to the public, this regime aligns with the delivering services to society approach (Pahl-Wostl 2019).

NPG can, as the newest regime, be viewed as a reaction to experienced NPM shortcomings, and as a strategy to comply with citizens demanding more influence than through the ballot box alone. This regime, therefore, emphasizes governing on the basis of equality, dialogue, and coproduction (Sørensen 2020). Within this framework, the state is seen as a pluralist unit, governed from a neocorporatist point of view, where trust and relational contracts regulate service processes and outcomes. Nonpublic partners are seen as preferred suppliers, often interdependent agents, with active and ongoing relationships in already established networks. Citizens are framed as someone that can exert influence; thus, the regime emphasizes processes where citizens can have influence beyond the limits of the representative democracy, aligning this regime with the "be a partner to society" approach (Pahl-Wostl 2019).

While the key elements of TPA and "setting rules" remain law, rules, guidelines, bureaucracy and the hegemony of professionals in service delivery, NPM and "delivering services to society" pays attention to lessons learned from the private sector; cost management, input and output control, competition, and contracts. In contrast to these, NPG and "be a partner to society" focuses upon the active citizen that can exert his/her influence upon both state and own situation. Thus, this last regime is often viewed as the preferred tool for mending the distrust to politicians presently found throughout western societies, often leading to populism and polarization. Implementing processes and mindsets belonging to this last regime can therefore be of great importance in the field of forestry to avoid such destructive processes. All relevant stakeholders ought thus to be involved in the innovative development processes of instruments meant to stimulate CSF.

Based on literature review and schematic structure of environmental governance from Lemos and Agrawal (2006), Fig. 14.1 shows the classification of key policy instruments that can be used to address the implementation of the CSF concept.

As mentioned above, the three major types of governance structures are hierarchy (command-and-control), voluntary (market-based), and community cooperation. Hierarchy or command-and-control instruments are based on the power of the state to regulate private actions through laws and regulations (e.g., Vatn 2010). An example is direct regulation, for example, in the form of obligatory, minimal percentages of given tree species planted during reforestation.

Hierarchy command-and-control instruments represent direct regulation by local, state, or national governing bodies. However, some types of regulation could stimulate or frame certain market-based tools (e.g., the European Commission (EC) regulations on ecolabel, mark of origin, organic products) and even some community tools (e.g., the EC regulations related to the so-called Leader approach).

Market-based instruments are based on voluntary exchange. These could include regulations or institutions that affect behavior through market signals (Stavins 1998). An example of such instruments may be payment for ecosystem services (PES). Most authors (e.g., UNECE and FAO 2018; Prokofieva and Gorriz 2013) 


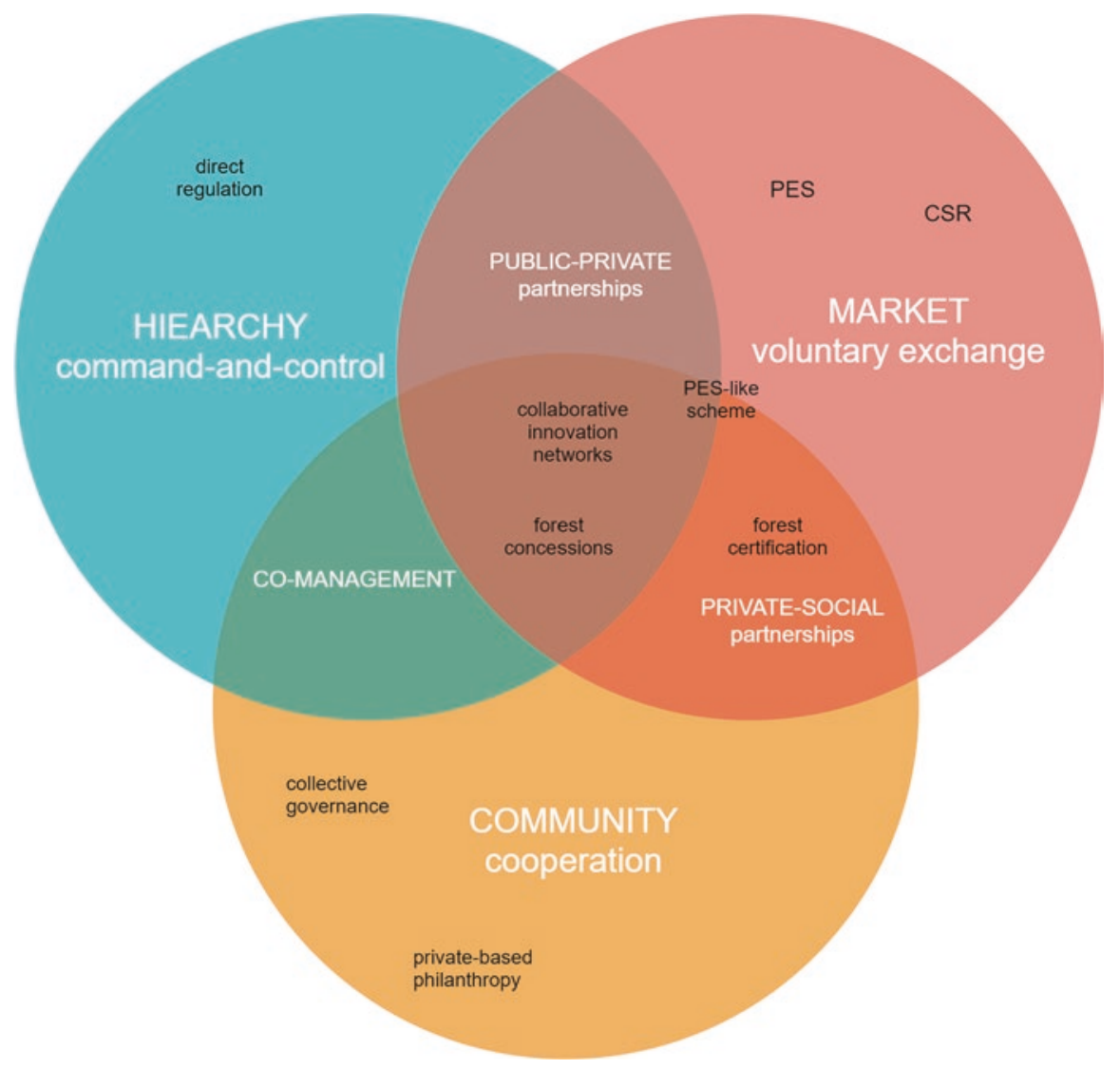

Fig. 14.1 Classification of key policy instruments with potential application within CSF $(P E S=$ Payments for Ecosystem Services; $C S R=$ Corporate Social Responsibility). (Based on Lemos and Agrawal 2006: Fig. 1; and Vatn 2010)

have adopted the PES definition from Wunder (2005). According to his definition, PES must comply with five characteristics (Wunder 2005, p. 2): “(1) a voluntary transaction, in which (2) a well-defined environmental service (or a land-use likely to secure this) (3) is bought by at least one buyer (4) from at least one provider (5) if and only if its provision can be secured (conditionality)." If a PES scheme does not fulfil all (but at the minimum one) of the conditions, it is called a PES-like scheme (Wunder 2005). Some PES-like schemes or mechanisms may fulfil the criteria of the command-and-control category rather than market-based. In practice, PES schemes are mostly hybrid systems based on both market and nonmarket instruments (e.g., Higgins et al. 2014; UNECE and FAO 2018).

Community-based governance is based on cooperation with and between local actors, creating a sense of community ownership. Collective governance is an 
example of community governance. Private-based philanthropy is another example of an instrument building upon community.

However, instruments often simultaneously hold aspects that reflect and are constituted by more than one of the structures mentioned above. As such, these instruments are to be found in the intersections between the main governance structures described by Vatn (Vatn 2010).

Public-private partnership is created through a combination of hierarchy (command-and-control) and market instruments. It represents cooperation between state agencies and market actors (Lemos and Agrawal 2006). An example is forest concession, a temporary allocation of typically state-owned public forest resources to another actor (companies, communities, or nongovernmental organizations NGOs), in order to regulate timber production to be compatible with the need for protection of the ecosystems, and the rights of indigenous people and local communities (Tegegne et al. 2018).

Comanagement connects hierarchical governance structure and community cooperation and represents cooperation between state agencies and communities. Such examples are information campaigns or voluntary certifications schemes.

As shown in Fig. 14.1, there can be identified instruments, which combine all three major governance types. Corporate social responsibility (CSR) and in particular Collaborative Innovation Networks (CoINs) are included in this category. The CSR concept connects elements of voluntary behavior, mandatory responsibilities, and societal expectations (Carroll 1999; Brammer et al. 2012). CoIN is mostly perceived as a self-organized and motivated group of actors (enterprises, universities, research institutes, governments, intermediaries, etc.), elaborating a collective vision, collaborating not only face-to-face, but also through Web or other platforms (Gloor 2007; Wu et al. 2019).

As seen in Fig. 14.1, different types of instruments based on different governance structures can be identified. We recognize primarily instruments, such as direct regulation, PES and PES-like schemes, certification, information campaigns, collaborative innovation networks and private-based philanthropy, or corporate social responsibility.

\subsection{Direct Regulation}

Direct regulation (or direct control or administrative instruments of regulation) is based on the legitimacy and power of a state to regulate private actions (Holzinger and Knill 2004; Vatn 2010). Legal regulations may come under legislation of local, state, regional, or European Union (EU) governments. In every country, the direct regulation in forestry exists in some form - it is mainly based on protection of forest in terms of determination of what is permitted and what is illegal (McManus 2009). The underlying principle is to set standards or targets (e.g., for lodging, maintenance, renewal, etc.) by a government authority that has to be complied with. If the standards or targets are not fulfilled, negative sanctions and penalties may occur 
(Baldwin et al. 2011). Direct regulation has been used since the beginning of environmental policy making by industrialized countries in the 1970s (Böcher 2012). Its advantage is speed and clearness. In case of functioning control, the meeting of preset targets is expected. On the other hand, fixed standards and rules are reactive and rigid. If fulfilled, no other motivations for desirable behavior exist. Economists stress the problem of high compliance costs and expensive control that results in generally low economic efficiency of this kind of intervention (Tietenberg and Lewis 2018).

The example of national regulation of forestry and forest management is the Federal Forest Act in Germany. German forest policy defines rules relating to forest, forestry, and timber utilization. The aim is to deal with conflicts of interests between the various economic, ecological, and social demands. The act is accompanied by other acts (e.g., Act on Forest Reproductive Material, the Timber Trade Safeguard, the Federal Hunting Act, and others). Comparable acts can be found in other European countries. Acts can be supplemented by various strategies, since these general acts mainly do not deal with changing social and environmental conditions, such as climate change. An example from Germany in this context is the Forest Strategy 2020. However, since this strategy addresses climate change mitigation and adaptation broadly, it does not state specific goals for mountain forestry (Federal Ministry of Food, Agriculture and Consumer Protection 2011).

National rules for afforestation might be considered relevant direct regulation within climate change policies. In many countries, however, including Czech Republic, the landowner cannot freely decide to change the arable land or pasture into forest. The Czech Act on the protection of the agricultural land fund defines the rules for exemption of land from the fund and levies for exemption of agricultural land. For afforestation of agricultural land consent of the state administration authority is always required and levies for exemption are set. Levies are not set only for land in the lowest levels of protection (fourth and fifth level of protection). It is also required to change the land to land for forest function in case of afforestation of land in the third level of protection. In other words, the owner cannot use the land for plantation or forest monocultures. Agricultural land in the first and second level protection may be withdrawn only in cases where the other public interest significantly outweighs the public interest in the protection of the agricultural land fund.

On the other hand, forest expansion has been one of the most prominent land use changes encouraged also by the introduction of a legal framework for afforestation payments in the reform of EU's Common Agricultural Policy (CAP) (Kotecký 2015). However, while the governments in the EU had built up a legislative framework for afforestation support scheme, this is not a direct regulation. By contrast, there are also additional agri-environmental subsidies paid under Rural Environment Protection Scheme (RESP) adopted with the reform of CAP in 1993. Nevertheless, the legislation and direct regulation, for example, in Ireland, caused decreasing interest of farmers in planting trees, since land under RESP could be withdrawn after 5 years, while the decision of afforestation was irreversible under current legislation (McCarthy et al. 2003). 
In the European Union, the formulation of forest policies is the competence of the Member States. Different examples of direct regulations at the EU level affecting forestry are hidden in other directives. One such example is The Fauna-FloraHabitats Directive (92/43/EEC - FFH or Habitat Directive). Very limited requirements for forest management can be identified in the Directive (Winkel et al. 2009), but Rosenkranz et al. (2014) investigated income losses in forestry due to the implementation of Habitat Directive caused by reduction of the amount of harvested timber. Since approximately $5.2 \%$ of the total German forest area had not been subject to a special protection status before (Sippel 2007), annual income losses for the enterprises averaged 31 to $39 € /$ ha (Rosenkranz et al. 2014). Direct regulation can, therefore, by spillover effects, be an efficient means for the implementation of CSF. The aim of the Habitats Directive is biodiversity protection regardless of implementing CSF.

It can be stated that direct regulation is, in principle, efficient until the calamity. Among the most common disasters in European forests induced by climate changes are fires, pest outbreaks (e.g., bark beetle), windstorms, ice storms, and drought (Seidl et al. 2014). Pests have especially caused problems in mountain forests of East-Central Europe, since increasing temperatures (among other factors) created better conditions for forest pests at higher mountain sites (Battisti and Larsson 2015). Unfortunately, there is no evidence of direct regulation dealing with CSF. Also, there is a lack of direct regulation that deals with prevention of climate change related issues. Mourao and Martinho (2016) examined the effectiveness of Portugal's direct regulation, regarding fires in forests. Their findings are in line with the claim that direct regulation is mostly reactive. Although there have been problems associated with the frequency and incidence of forest fires since 1980, Portuguese legislative documents on forest fires follow the evolution of fire. This direct regulation tends to be unable to prevent the dimensions of abiotic forest factors (Mourao and Martinho 2016: 476). They added that both legal instruments instability and conflicts are other problems that do not contribute to achieving desired results (Mourao and Martinho 2019). Conversely Fernandes et al. (2017) claim that crises should be an opportunity, or trigger, for change or reforms. However, they also noted that sudden and reactive changes in (fire-related) legislation can cause confusion (Jensen and McPherson 2008) by reason of the bounded rationality and selective attention to relevant information (Busenberg 2004). It can be stated that direct regulation cannot prevent any problems or calamities, but it should prevent an escalation of the problems.

\subsection{Collective Governance}

Since the 1970s, there has been a growing awareness of negative social and environmental problems caused by attempts to control very complex natural systems. There has also been increasing criticism of conventional command-and-control-based resource management, and innovative approaches to understanding and managing 
environmental and social systems have emerged (Secco et al. 2011; Paavola and Hubacek 2013). An adaptive collaborative approach did not take hierarchical management as a starting point but, on the contrary, positions itself by introducing the concept of "bottom-up" management (Fraser et al. 2006). It is expected that actors traditionally involved in forest-related decision-making also will address and apply new concepts and tools, such as public participation, shared responsibility, and networking in governance mechanisms (Secco and Petenella 2006; Secco et al. 2011; Lovrić et al. 2012; Niedziałkowski et al. 2012, 2015; Paloniemi et al. 2015; Primmer et al. 2015). Depending on the sector and context, forest governance may be dominated by private actors, NGOs, public authorities, or others, which are a mixture of theoretically equal actors. The difference in governance modes "lies simply in who is involved in making common choices" and how the one's involvement is managed.

In Northern and North-Western European countries, private ownership of forestland ranges from about $40 \%$ to $80 \%$, and in Eastern European countries from $10 \%$ to $60 \%$. In Western and Central Europe, small (up to 5 ha) land-holdings represent about $85 \%$ of all forest owners (Schmithüsen and Hirsch 2010). In countries with a large share of private forest owners, high fragmentation, and large number of owners, various forms of decentralized partnerships or even private governance are more common (Beland Lindahl et al. 2017).

These private forests are very important as they have significant potential for the production of wood and nonwood products, provision of multiple ecosystem services, including carbon storage and biodiversity conservation (Osman-Elasha et al. 2009). On the other hand, their role in the wood market has been, and still is, small. In order to strengthen their position, the first Forest Owners' Associations (FOAs) have emerged in Europe already at the end of XIX, and beginning of XX century and they have become very common over time (Weiss et al. 2011; Kronholm 2015; Aurenhammer et al. 2017). The organization and functioning of FOAs reflects the way forests are governed, which is based on the cooperation of local actors who create a sense of community ownership. The term "collective governance" was introduced by Ostrom (1990), while Armitage (2005) presented the principles of community resource management.

There are numerous definitions of forest governance, but the definition proposed by Lockwood (2010), that is, "the interaction between structures, processes and traditions that determine how power and accountability are exercised, how decisions are made and how citizens or other stakeholders have their say," seems to be the most appropriate to describe collective governance. This term, however, does not mean either equal sharing of power or a high level of stakeholder involvement.

The community forestry's basics include such objectives as empowering forest users, and improving the condition of the forests, by means of managing forests by local stakeholders, for commercial and noncommercial purposes (Vizzari et al. 2012). FOAs regulate the use of the natural resources and take care of all aspects of community life (Vizzari et al. 2012). They also focus on sustainable collective governance outcomes, such as the quality of the decision-making, efficiency of the implementation process, and sensitivity to different context-specific aspects. Thus, when evaluating community forestry outcomes, it is especially important to state 
whether this governance mode has delivered what was expected (Maryudi et al. 2012).

If any conflict emerges, FOAs try to overcome it taking into consideration interactions among ecological functioning, social structures, and stakeholders' participation (Paavola and Hubacek 2013). The gained expertise is invaluable in the process of continuous collective learning (Secco and Petenella 2006; Sandström 2009; Saarikoski et al. 2012). Broad argumentation, inclusive stakeholder participation, and genuine knowledge sharing are considered to contribute to positive outcomes (e.g., Reed 2008).

As mentioned before, the community forests are managed by the forest owners themselves. In France, however, the FOAs' forests are used by the forest owners, but they are managed by the National Forest Office (NFO). For the discussions with NFO, the forest-owning communes are represented by their federation (FNCoFor) (Chauvin 2012). Such a share of decision-making between the private and the state actors results in the comanagement governance mode.

The "forest territory charters" (CFTs), that is, participative strategic processes carried out at a local level, were instituted on the basis of the French forest law of 2001. The CFTs were conceived as a policy tool for promotion of the principles of SFM in community forestry. Different stakeholders at all scales have seized this tool to adapt it to their own strategies. The CFTs have influenced these policies in the long run, even changing economic conditions and governments (Chauvin 2012). A mission of coordination of the CFTs, given to the FNCoFor by the national government, resulted in a conversion of the FNCoFor toward a reliable intermediate to promote the CFTs as a bottom-up approach. It induced a firm empowerment of the FNCoFor, evolving from a simple political representation, in a state-steered device, to a strong lobby system, shaped as a support network with expertise in both forestry and rural development, while NFO had to withdraw to technical matters notably due to the costs of participation (Chauvin 2012). It is not clear, however, whether the FOAs governance mode is the same as before the CFT initiative was undertaken or if it has changed into collective governance.

In 1992, the federal government of Canada set up a collaborative governance initiative through the Model Forest Program (LaPierre 2002; Parkins et al. 2016). The government's idea behind the initiative was to allow an initial 10 Model Forests (MFs) across the country to act as demonstration sites for SFM, while the government initially provided core funding and leadership. Such a share of responsibilities between the MFs and government might be identified as the comanagement. The mandated structure called for an industrial partner as well as a commitment to accommodate not only the local residents and representatives of the government, but also First Nations, NGOs, and individual persons interested in the MF goals and their mode of action (Hall and Bonnell 2004; Rametsteiner 2009; Parkins et al. 2016). Yet, the presence of the industrial partner in the MF partnership resulted in a change of the governance mode from comanagement to corporate social responsibility (CSR).

Since the concept has shown itself to be flexible and adaptive to its setting (Besseau et al. 2002; Ho et al. 2014; IMFN 2019), what once began in Canada is 
now the world's largest network consisting of more than 60 MFs across the World, of which 10 have been established in the EU countries (IMNF, 2020). Each MF is unique but all of them are governed by the same principles of trust, transparency, and collaborative decision-making (IMFN 2019, 2020). MFs are proven examples for good governance effectiveness and efficiency as well as shared stewardship of forests and the larger landscapes that surround them (Rametsteiner 2009). It has to be noted that the Canadian suggestion of incorporating the industrial partner has been adopted just by a few MFs outside Canada (Shingo 2017). On the contrary, the majority of the MFs adopted the collective governance mode, since they are not any longer financed nor led by the respective national states but, by acquiring a legal identity, they were able to function, thanks to grants awarded by foundations, aid agencies, and the local, national, and international institutions and organizations.

\subsection{Voluntary Certification Schemes}

Forest certification is a voluntary market-based instrument to achieve SFM. Voluntary instruments aim to change the forest owners' and forest managers' behavior without the force of law (van der Heijden 2018). Originally, it was introduced in the early 1990s to address concerns of deforestation and forest degradation, to protect forest biodiversity and to mitigate illegal logging (e.g., Cashore et al. 2006; Stupak et al. 2011), especially in the tropics (Rametsteiner and Simula 2003). The goal of labelling wood products based on forest certification is an identification of products from well-managed forests (Elliot and Schlaepfer 2001). Such initiatives are always addressed by independent third parties (Elliot andet Schlaepfer 2001; Buliga and Nichiforel 2019), mostly nongovernmental organizations.

The aim of the forest certification is to promote SFM with two tools: criteria and indicators (Rametsteiner and Simula 2003). There are currently several international certification schemes defining specific sets of standards for sustainable forest management. Two forest certification schemes are present across Europe: the Forest Stewardship Council (FSC $®$ ) and the Programme for the Endorsement of Forest Certification (PEFC ${ }^{\mathrm{TM}}$ ) (Buliga and Nichiforel 2019). PEFC is an international umbrella organization for approving national schemes. Most countries are involved in these two processes. Both schemes include criteria for best practices in forest management, covering environmental, and social and economic aspects. The area of the world's forests covered by these two schemes increased from 14 million hectares in 2000 to almost 420 million hectares in 2014 (FAO 2016: 26). Even though the original purpose for the establishment of such a scheme was to protect mainly tropical forests, most certified forests are in the temperate and boreal zones, with Europe as the most important region (Rametsteiner and Simula 2003).

In addition to the certification of forest management, there is also the second type of forest certification. Certification of the chain of custody (CoC certification) verifies that certified wood material product has been taken from forests and managed according to responsible forest management standards (Buliga and 
Nichiforel 2019), and that it has been kept separate from noncertified material through the production process. This chapter is focused on certification of forest management.

The advantage of the instrument of certification is its voluntary nature and provision of benefits, not only to forests owners, managers, entrepreneurs, or timber companies. As a final result, certification helps to achieve social and environmental goals. This is facilitated by the set of criteria and standards. The FSC forest management standards include 10 principles and related criteria to confirm that the forests are managed economically and also in a way that preserves natural ecosystems and the social benefits of local communities and workers (Buliga and Nichiforel 2019). In order to receive FSC certification, all of them must be met. They include, for example, compliance with laws (including national laws, international agreements, etc.), contribution to maintaining, conservation and/or restoring of ecosystem services and environmental values, obligation to maintain and/or enhance the high conservation values through applying the precautionary approach (FSC 2015).

Among the main motivations for participating in forest certification are the following: landowner interest, knowledge and awareness, alignment of certification aims with landowner's values, low cost, market access, and benefits (e.g., BoakyeDanquah and Reed 2019). Public image or feedback on management practices are mentioned by community-based forestry practitioners, while their expectations for economic benefits are low (Crow and Danks 2010). According to research from the USA, access to professional forest management advice or information is a significant factor in seeking forest certification (e.g., Ma et al. 2012).

The criticism of forest certification is mainly focused on its minimal impact on tropical forest deforestation. Another disadvantage can be seen in dependency on local law. According to their research based on comparative analysis of Poland and Belarus, Niedziałkowski and Shkaruaba $(2018 ; 180)$ stated that the effectiveness of FSC depends solely on the strong support of the government and can collapse if the support is withdrawn. In both cases, the role of the state actors was crucial in the forest certification process. This is in all probability broadly valid in countries where the state is a dominant forest owner, for example, postsocialist countries. Furthermore, a Romanian case study (Buliga and Nichiforel 2019) evaluated how much of the FSC standard is contingent on legal rules in the country. They concluded that $69 \%$ of certification requirements are addressed in law. They added that the effect of certification is mainly about contributing to a better enforcement of the existing legal rules.

It can be stated that forest certification can help with the introduction of climate smart forestry and that forest certification is a usable instrument for achieving environmental goals. It seems that especially small owners welcome the information and advice about SFM. In combination with information campaigns, forest certification can be seen as an effective additional instrument for fostering climate smart forestry, together with legal rules, and command and control instruments. However, it should be supplemented by raising the awareness of forest owners, or by demonstrating the economic benefit. Benefits are mostly affected by the demand for certified products, which in turn is related to general economic indicators (FAO 
2016). Nevertheless, since the common reason for participating in forest certification schemes is public image, it should be effective also to raise public awareness. Disadvantages or problems of such instruments could be the necessity to have the independent third party, which supports and guarantees the certification program.

\subsection{Private-Based Philanthropy}

Most instruments require the involvement of different public administration levels. Specific legislation or other official documents with rules need to be issued and particular bureaus need to be empowered, so an instrument starts functioning. Instead, private-based philanthropy deals with the independent action of property owners that from different reasons pursue common interests, being its biodiversity enhancement, water retention, or CSF. While doing so, they (voluntary) sacrifice short-term economic benefits from using the land.

Private-based philanthropy may involve the action of an individual landowner or a nongovernmental organization. Its most spread form is so-called land trusts, private protected areas with long tradition particularly in the USA and Australia (Bennett et al. 2018). Within Europe, some forms of land trusts exist in the majority of Western European countries, especially the UK. Usually, their main goal is to acquire the land and to conserve it for biodiversity enhancement purposes. In order to gain money to acquire the land and to manage it, land trusts receive private donations. In the USA, the functioning of land trusts is supported by the existence of conservation easements. These are voluntary legal agreements restricting some property rights of the owner - therefore, a land trust does not buy the land itself, it only buys part of the land use rights and monitors if the conservation occurs (Horton et al. 2017; Graves et al. 2019). Landowners participating in conservation easements may receive some financial benefits, including income, tax credits, or tax relief on their decreased property value. Bastian (2017) proves that this financial motivation together with pursuing common interests is attractive for landowners apart from financial incentives, a desire to protect the land in perpetuity or to maintain a connection with land is an important impulse.

Except for typical nongovernmental organization (such as land trusts) engagement, individual landowners may also pursue common interests voluntarily even when receiving no financial compensation. They do it especially if: a) they believe that what they do is the right thing, b) their living is not fully dependent on the economic use of the land. This is, for example, the position of the "philanthropic farmer" in Czechia, as described by Slavíková and Raška (2019), who decided to build natural water retention measures on his field from his own resources despite the fact that he reduces the extent of the farming land and subsequent agricultural subsidies.

This evidence shows that private actions may support (not only undermine) public policy goals. Their focus does not need to be limited to biodiversity conservation or water retention as mentioned in examples above. SFM or even CSF - if the 
private land in focus is a forest - might be considered as well. In Czechia, some existing land trusts aim at forest renewals considering the specific species composition adapted to changing climate. Čmelák was established 1994 and represents newly established land trusts in the form of a nongovernmental organization, where members of the NGO share common interest in deciding about the type of forest activities as the Board, or during Membership meetings. In the early1990s, members were concerned with the poor condition of forests in the North of Bohemia in the Jizera Mountains, mainly caused by sulfur emissions and bark beetle. Acting together with volunteers, and raising money from public donations, Čmelák bought the land. They changed spruce monoculture into mixed forest called "New Virgin Forest" (Špaček et al. 2020). Ongoing management of the New Virgin Forest is mostly financed by subsidies (grants) and donations. The PES scheme represents an important part of the donation in Čmelák (see next Sect. 14.5). Čmelák implements their activities in a relatively small area. Long-term goal of Čmelák's activities is to show novel ways to approach and implement financially self-sufficient SFM focused on nontimber forest products.

Private-based philanthropy will rarely solve problems worldwide. The rationale to promote and even establish private initiatives is mostly rooted in their potential to effectively overcome land-use conflicts and institutional misfits on fragmented land.

\subsection{Market-Based Instruments: PES and PES-Like Schemes}

This section introduces examples of the implementation of payments for ecosystem (or environmental) services (PES) scheme, while more detailed description of PES as an incentive tool for behavioral change to climate-smart practices can be found in Chap. 12 of this book: Gežík et al. (2021).

According to the previously mentioned definition of the PES scheme, the Land Trust Association Čmelák (Czechia) can be seen as an example of a PES-like scheme, since it complies with characteristics defined by Wunder (2005, p. 2): "(1) a voluntary transaction, in which (2) a well-defined environmental service (or a land-use likely to secure it) (3) is bought by at least one buyer (4) from at least one provider (5) if and only if its provision can be secured (conditionality)."

The main activities of Čmelák are based upon buying land with spruce monocultures in the Jizera Mountains and changing them into mixed-forest, so-called New Virgin Forest. Their activities are geared toward nature protection and conservation. Besides revenues from services (ecological education, sale of seedlings, etc.), subsidies, and grants, Čmelák obtains significant resources by selling Certificates of Patronage. Local citizens, public, or companies voluntarily buy this certificate to help with financing Čmelák's activities and extension of New Virgin Forest. Buyers become a patron of New Virgin Forest and contribute toward the creation of nonmaintained forest providing nontimber forest services (educational, recreational, 
etc.). The main problem may be seen to lie with the revenue generated by selling certificates, since this amount is sufficient for buy-off of new land; however, additional resources are required for other activities (maintaining New Virgin Forest).

Given that SFM in mountain forests can provide important regulation services (carbon sequestration and storage, water regulation and protection of soil, people, and infrastructure against hydrogeological hazards, etc.), groups of stakeholders may be willing to pay and compensate forest owners from losses occurring due to SFM and reducing timber harvesting as a means of lowering the risk of damage to buildings and people (Grilli et al. 2020).

The quantification of the monetary value of services is always important for performing PES. Olschewski et al. (2012) and Grilli, et al. (2020) describe monetary valued avalanche protection by forests in Swiss Alps using choice experiment and determination of willingness to pay for the protection. They conclude that willingness to pay is at a level of per household costs of alternative measures, and furthermore substantially higher than the costs of measures needed in forests to maintain protection based on engineering and silvicultural knowledge. The study shows examples where PES schemes should be an efficient solution for (in this case) avalanche protection in mountainous regions.

Studies indicate that the monetary valuation and setting the amount of payment is the most challenging factor when implementing PES schemes. Nevertheless, it is considered as an effective and already used instrument for changing forest management to SFM. PES scheme may provide important sources and compensations for forest owners for losses occurring for reducing timber harvesting.

\subsection{Collaborative Innovation Networks}

To ensure that instruments for CSF have impact, it is vital to check they are in accordance with present contexts. Standardized solutions and instruments should not simply be "put into use." Rather they must undergo a process where their appearance and usage become adapted, adjusted, and implemented in a manner that ensures correspondence with the expectations, motivations, and values of those affected by, or wielding, the tools. To ensure accordance between chosen instruments and society. Collaborative innovation networks (CoIN) may seem a promising method. Still, in their traditional format, CoINs are probably not by themselves sufficient to achieve the anticipated alignment between instrument and present challenges.

As a concept, CoIN was introduced to describe how multiple partners, through collaborative action, possess the power to successfully instigate products, services, policies, processes, business solutions etc. CoINs are mostly perceived as selforganized and motivated groups, consisting of actors like enterprises, universities, research institutes, and governments that, by means of collaboration, elaborate a collective vision. Such networks are highly plastic and adaptive, and able to adjust to local or temporal situations, both concerning time and space (Gloor 2007). Such 
networks can therefore easily be understood as viable networks, possessing great potential for CSF.

Several examples of CoIN in forestry and rural development can be located. The two presented below are representative for those found when trawling the Internet.

The "Innovation Networks of Cork, Resins and Edibles in the Mediterranean basin" aims to foster communication and knowledge transfer to highlight how enhanced fluxes and multi-actor networks can help to seed real and effective innovation of NWFPs and contribute to business discovery, social innovation and the co-design of locally adapted innovative value chains (https://www.incredibleforest.net). Still, from a CoIN-perspective the network lacks representation from the societal side, except through proxies, like NGOs.

The "PIRIC-network" of New Zealand (https://www.piric.org) aims for a sustainable future for New Zealand through accelerating the adoption of digital technologies into their Primary Industries and Regional Economies, realizing they can no longer act as individuals or organizations working alone. With industries and communities entering a time of significant disruption, rapid increase in consumer acceptability, and changes to the international trading environment. Even with a number of founding members from the societal sector, there still is a lack of real involvement into the core areas of activity by the relevant societies.

The common factor of these, as well as of the other examples found, was their focus on societal involvement, while still displaying a top-down structure. Nowadays, this may not be sufficient, since it is increasingly evident that it is both ethically and practically doubtful to let innovation processes be governed solely by the traditional actors, logics, and forces. This stems from the experience that, despite research and innovation improving our lives in almost every area, one also sees the transformative forces of innovation creating new risks and dilemmas.

To promote real involvement and reduce the risks of negative impacts from expert-dominated innovation, the concept of Responsible Research and Innovation (RRI) has been developed and implemented. To reduce negative "side effects" from research and innovation, RRI demands the involvement of citizens and communities in an upstream fashion, to ensure outcomes being aligned with the values of society (RRI-Tools 2020; Stokken and Børsen 2020). Thus, important funding frameworks, like Horizon 2020 and COST as well as several national funding schemes, require the implementation of RRI in all projects and activities.

RRI rests upon a normative framework, comprising the six policy keys: 1) ethics, 2) gender equality, 3) governance, 4) open access, 5) public engagement, and 6) science education. In our CSF context, the six keys denote that a CoIN process instigated to assure accordance between instrument and context, ought to be governed by civil servants that adhere to the NPG regime (Sørensen 2020) and the "be a partner to society" approach (Pahl-Wostl 2019). In particular, the governance and public engagement keys demand comprehension and the use of networks to be integrated parts of development and innovation processes.

To engage in networks in a manner where RRI is taken seriously, civil servants must employ a novel position, where both citizens and other relevant actors are provided with the possibility of being involved from the very start. Only then can the "current demand" for governed innovations, where people have a right to be heard, and where the inclusion of citizens' knowledge, resources, and motivation 
actively contributes to successful implementation, is met. To achieve this, citizen involvement must take the form of real debates (Force free discourses - in the terms of Habermas (1995)), where the say of the citizens surpasses tokenism (Arnstein 1969). An example of such an arrangement is how Ireland established citizens forums to foster dialogue around abortion to prevent domestic polarization. Another example is from Denmark, where a municipality that established ad hoc political committees at the core of their policymaking experienced that citizens' involvement transformed from demanding to actively seeking and promoting solutions (Sørensen 2020).

When problems, like those in Ireland and Denmark, transgress being a matter of finding the most bureaucratic sound or economically most viable solution, to being a matter of democracy, governance, ethics, and engagement on equal terms for all citizens, a problem often transforms from being a difficult question to a so-called wicked problem. The complexity and constant change that characterizes societal development has given rise to this concept (Churchman 1967, Rittel and Webber 2007), reflecting a reality in which societal problems in general tend to be governed by incomplete, contradictory, and/or changing requirements that are difficult or impossible to solve in a "right" way.

In our context, the core lesson in the development of instruments for CSF, therefore, relates to the need to always be looking for the feasible solution, understanding that the traditional positivistic science often fails to describe the societal processes encompassing policy development and implementation conditions. This calls both for a process-oriented approach, and a willingness to adapt and seek new solutions.

To get the best out of CoINs, it is therefore important not to "marry" one specific method or solution, but to keep an open view, looking for "solutions that can work" in this particular setting on the basis of a focus on the process rather than on the output. In this matter, being aware that collaboration possesses the power to contradict the traditional linear, deterministic models, while on the other hand generating results that are more depending on the conditions under which they are developed, than the actual resources and the factual actors involved. Thus, two parallel processes, involving the same set of actors, but separated in space, or sharing the same space but separated in time, may well end up in different solutions. And even more that the choice of and inclusion of whom to consider as stakeholders largely will define the potential power of the outcome.

Approaches can, as argued, be utilized in a variety of modes of collaboration, for example, in partnership models, triple- or quadruple-helix models, communicative planning models, or actor-network models. The essence and their commonality are the ability to open up for broad and inclusive cooperation, where new solutions may be found and thus induce improved conditions for implementing. These may be reached through addressing three crucial aspects:

- Perspectives. More "heads" involved may give rise to a wider variety of solutions.

- Inclusion. Working together fosters trust. 
- Feasibility. Trust eases the ground for easier and more successful implementation.

In market situations, this approach opens opportunities for partners/collaborators to increase their profits. In nonmarket situations, for example, regarding environmental services regulation and provisioning, giving rise to novel approaches, and in particular to what could be easier, more rapid and improved conditions for implementation.

CoIN further bridges with models of interacting spheres, like the classic threefold sustainability model (see Fig. 14.2) or John Friedmann's 4-Life-worlds, in that they acknowledge the need for pluri-sectoral, or cross-sectoral cooperation. And, as well, representing sectors/realms outside of direct human control. Like naturalsystems-based design, where one tries to mimic nature's solutions and to recreate them into modern day, human designed environmental solutions.

Thus, alliances with and among the stakeholders are needed, surpassing both the traditional bureaucratic approaches where the civil servants were the masters, and the approach denoted by New Public Management where the civil servants have the serving role. Rather, the servants must embrace the collaborative role, where the goal is to empower citizens as individuals and groups, and to build implementable and feasible solutions together. CoIN processes, in accordance with the

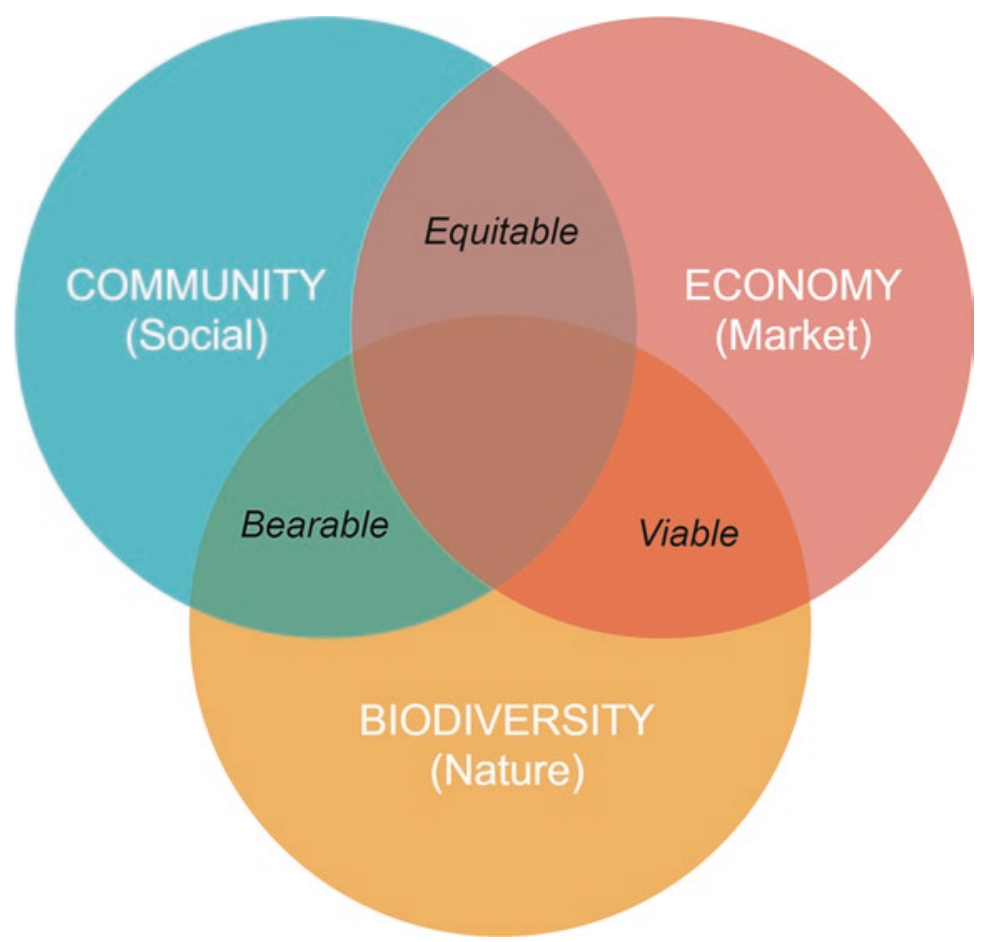

Fig. 14.2 The three spheres model of sustainable development (with overlaps labeled). (based on Thatcher 2015) 
Pan-European policy requirements for RRI, involving all relevant stakeholders and assuring that the solutions chosen serves the greater good, are therefore vital to achieve sustainability over time. Thus, CoIN possesses the potential to be understood as a tool to address wicked problems of great complexity within the field of CSF, at least if all relevant stakeholders are heard, instead of only the actors in control.

\subsection{Corporate Social Responsibility}

Corporate Social Responsibility (CSR) has no known accepted formal definition. CSR refers to the contributions of companies to the society as a whole or to particular communities, often directly related to companies' operations. It goes beyond legal regulations of the activity of companies resulting from volunteer decisions of companies to balance internal profitability and other corporate objectives with positive impacts in the society.

Although the concept can be traced back to the 1950s, the use of CSR in practice is relatively recent (Hajdúchová et al. 2019). The World Business Council for Sustainable Development defined CSR as "the ethical behaviour of a company towards society," or "management acting responsibly in its relationships with other stakeholders who have a legitimate interest in the business - not just the shareholders" (WBCSD 2000). In the same report, the WBCSD states that CSR "is the continuing commitment by business to behave ethically and contribute to economic development while improving the quality of life of the workforce and their families, as well as of the local community and society at large". This includes environmental responsibility, together with financial and social.

Starting in the 1990s, the global adoption of the concept of sustainable development in international and national level policy in making and regulatory frameworks has strongly contributed to integrate social and environmental dimensions into the responsibilities of businesses. This has contributed to make CSR a synonym of sustainability (Panwar and Hansen 2008). The integration of sustainable development into CSR has contributed to making CSR an important mechanism related to the prevention of undesirable impacts of companies to society (avoiding pollution or protecting species habitats) and/or supporting local communities around the world through donation of resources, time, or money, also from forest companies or companies operating in forest environments. Sustainable development is still today one of the major components of CRS together with social, environmental, and financial responsibility and company accountability (Lempiäinen 2011). With the general acceptance of the UN Sustainable Development Goals of the 2030 Agenda by the society at large, it is likely that sustainability will increase further its importance in CSR in the near future.

The growth of social responsibility within companies has evolved strongly in recent decades also due to changes taking place in societies in terms of the dominant values, rights, ideologies, and political and governance models, which influenced 
the expectations of the society from companies. Several other factors are also related to the increasing relevance of CSR, such as the contrast between the socioeconomic development context among sites in which companies operate and emergent drivers such as globalization, climate change, the biodiversity crisis, environmental catastrophes, forest fires and many others, increasing social and environmental awareness and, at the same time, creating opportunities for companies to become more socially responsible. Increasing connectivity and information exchange in societies have also increased the relevance of CSR, given the visibility of the work of companies as well as the impact of the public opinion and preferences on corporation's attitudes.

Social responsibility has become part of the business model of companies. Socially responsible entrepreneurship, socially responsible business, socially responsible marketing, and many other similar terms emerged in the businesses and corporation's arenas. Companies are today ranked according to their level of social responsibility (e.g., the Reputation Institute's World's Most Reputable Companies for Corporate Responsibility 2019), strongly impacting the public image of corporations.

ISO, the International Organization for Standardization, published in 2010 the standard ISO 26000 to address social responsibility, following years of a multistakeholder discussion process (ISO 2010). Based on the premise that "the objective of social responsibility is to contribute to sustainable development," ISO 26000 provides guidance on a series of essential topics, such as governance, human rights, labor practices, the environment, fair practices, consumer issues and community involvement and development, as well as practical guidance to integrate social responsibility in organizations, providing also examples of initiatives and tools for social responsibilities.

The social and environmental performance of companies has an effect on their investment efficiency (Guan et al. 2019). In the forest sector, companies benefit from CSR by improving relationships with stakeholders, maintain their legitimacy, address challenges, and achieve sustainable development as well as competitive advantages (Li and Gao 2019). Environment protection and promotion of employment seem to be the most relevant responsibilities disclosed by forest companies ( $\mathrm{Li}$ and Gao 2019). SFM and its certification has been followed as a major CSR practice by the forest industry in general. In the Congo Basin, for example, certification is the aspect of CSR most valued by timber companies (Colaço and Simão 2018). Environmental themes related to forest operations, education, and health are priority aspects for these companies based on their disclosing. SFM and accountability are the two most frequently reported by large top forest companies in all continents (Vidal and Kozak 2008).

In practice, CSR can be regarded as economic instruments with a positive impact on increasing the supply of ecosystem services through monetary donations and other investments by companies. One example is the "Cash crops used to protect Costa Rican forest" by a subsidiary of NUEVA and a subsidiary of Schmidheiny to prevent degradation of forest in slopes due to slash and burn practices through planting macadamia trees in a buffer zone between farms and cloud forests on the slopes 
of a Costa Rican volcano (WBCSD 2000). Another example is the Farmer Training Center (FTC), established by Rio Tinto near the Kelian mine in Indonesia, to promote sustainable livelihood after the mine closure (WBCSD 2000). Examples of these kinds of actions have been compiled for countries of the Mediterranean region including Italy (establishment of protected area in the Brenta River Forest), Greece (local forest fire volunteer groups), Morocco ("Partnership for Moroccan Forests"), and Tunisia ("Pact for a Green Tunisia") (Górriz-Mifsud et al. 2018). Another type of CSR initiatives in the forest sector includes investments in offsetting the carbon footprint of companies through voluntary forest projects in Italy and Spain (GórrizMifsud et al. 2018).

Particularly after the signature of the Paris Agreement in 2015 (COP 21), climate change has become a major concern of societies and governmental bodies. The pressure of citizens (and consumers) has increased so much that for companies, committing to the great challenges of the Paris Agreement is a necessity (Allen and Craig 2016). This is even a stronger pressure for companies than it is for governments. The trend is mostly toward reducing the carbon footprint of companies, which is an important component of corporation disclosures. Therefore, climate change creates a new opportunity for CSR to support climate action initiatives and policies, which can include CSF, in mountain, and other types of forests.

\subsection{Forest Concessions}

A Forest concession "is a contract between a forest owner and another party permitting the harvesting and/or managing of specified resources from a given forest area" (Gray 2002). It is a frequent form of forest tenure and forest management in many countries and bioregions, both developing and developed (Landell-Mills and Ford 1999; Gray 2002). Concessions have been, however, much more frequently used in tropical countries in West and Central Africa, Southeast Asia, and Latin America (Tegegne et al. 2018). In other regions, concessions have been used mainly in Canada, in the USA, and in Latvia, Russia, Montenegro and Slovenia, in Europe (Landell-Mills and Ford 1999; Gray 2002; van Hensbergen 2016).

Forest concessions is a general mechanism often used to manage state or community land, but it can refer to several types of contracts and forest land tenure forms that might include a large range of possibilities that vary according to management objective, but that also vary from country to country. In Indonesia, for example, Natural Forest Timber Concessions, Industrial Plantation Forest Concessions, Ecosystem Restoration Concessions, Non Forest Product Concessions are commonly used concessions for private companies in public forestland and Community Forest Plantations, Community Forests and Village Forests in communal forests (Buergin 2016).

Forest concessions contracts are established between public or private forest landowners and a private, public, community, aboriginal group, or cooperative partner (Gray 2002), according to a system of established national forest policies at the 
country level (Søreide 2017). These contracts can be of two kinds: forest utilization, allowing harvesting and/or use rights (nonwood forest products, game, conservation, and tourism) in public forests, and forest management services (Gray 2002). In the latter case, contracts can be directed to conservation or protection of forest areas, including the management of protected areas. Forest concessions often require measures of environmental restoration and/or protection, such as afforestation, even for forest utilization (Gray 2002). The monitoring of the concession system is usually the responsibility of governments, which can, however, be given to NGOs or private companies (Søreide 2007).

International forestry remains aligned with the framework where certification is the core process/outcome, although additional novel social and political frameworks have emerged, such as the Ecosystem Services concept and the UN Sustainable Development Goals. Forest concessions are seen today from the point of view of such approaches to deal more with conservation, or as mechanisms to halt deforestation and forest degradation in tropical countries (Tegegne et al. 2018).

Forest concessions are a type of tenure with the potential for supporting CSF, including mountain forests, through either logging contracts based on sustainable forestry principles, or through management contracts directed to conservation of forests and provision of ecosystem services and the adoption of adaptation measures. However, the negative results of forest concessions as a tool for sustainable forestry can be questioned given the proneness of concession systems to corruption, illegal logging, and other practices that not just deprive countries of financial benefits, but increase deforestation and degradation of forest systems (Gray 2002; Søreide 2007).

In European countries, forest concessions are today rare, since governments are able to profitably take control of all forest activities and operations in public forestland (van Hensbergen 2016). In Slovenia, the forest concession system, was replaced recently in state forests that are now directly managed by the state-owned forest company.

\subsection{Conclusions}

There are many policy instruments for forest management used with varying degrees of success. A wide range of instruments respond to direct regulation, which has been seen as insufficient to deal with natural hazards and calamities (see Sect. 14.1). An example with the potential to overcome potential land-use conflicts, and effectively contribute to CSF using private lands and private initiatives, can be seen in private-based philanthropy (see Sect. 14.4). As mentioned previously, property owners (voluntarily) sacrifice short-term economic benefits from using the land.

PES and PES-like schemes (see Sect. 14.5) can make a significant contribution to the introduction of CSF, while many provide important sources and compensations for forest owners for losses (or economic benefits from using the land), which occur due to reductions in timber harvesting. 
Instruments only work if they are implemented effectively. Thus, to ensure optimal implementation (See Sect. 14.6), the state must govern through alliances with the stakeholders, surpassing both the traditional bureaucratic approach where the civil servant knows the most, and the approach denoted from New Public Management where the civil servant has the serving role. Instead, the servant must take on the collaborative role where the goal is to empower citizens as individuals and groups to build implementable and feasible solutions together. Collaborative innovation processes (CoIN), in accordance with the Pan-Eurpoean policy requirement of RRI, both involving all relevant stakeholders and assuring that the solutions chosen serve the greater good, are therefore vital to achieve sustainability over time.

Another kind is corporate social responsibility (CSR; see Sect. 14.7). This concept connects elements of voluntary behavior, mandatory responsibilities, and societal expectations (Carroll 1999; Brammer et al. 2012). Furthermore, Forest Owners' Associations (FOAs; see Sect. 14.2) (traditionally also called "private forestry" or "community forestry") are governed under the mode of collective governance, but because of the strong position of industrial partners, the big FOAs, such as those forming the Federation, are governed according to the rules of CSR. For that reason the forest owners' associations in the Nordic countries use the word "family forestry" to denote private ownership at family level (Ackzell 2010).

One of the most advanced initiatives undertaken by the local and bigger regional FOAs, that delivered a new, voluntary governance instrument, is the PEFC developed alongside the FSC (see Sect. 14.3). PEFC is often considered as one of the most important private initiatives, due to the inclusion of stakeholder groups, such as environmental NGOs and social groups, for example, indigenous peoples, labor organizations, and forest owners in the schemes. PEFC is an example of customerdriven processes to foster SFM that regulates supply chains and markets of woodbased products, and is integral to environmental forest governance (Albrecht 2012). However, insufficient knowledge, low priority of biodiversity protection and mainstreaming nature's contributions to people, lack of transparency, as well as limited planning tools and resources, may reduce the effectiveness of PEFC. Despite their shortcomings, the PEFC schemes have proved particularly important for indigenous Sami people, who hold use rights to herd reindeer on about $30-50 \%$ of forestland in Norway, Finland, and Sweden (Blicharska et al. 2011).

A further example could also be a forest concession (see Sect. 14.8): contracts can be directed to conservation or protection of forest areas, including the management of protected areas. Forest concessions often require measures of environmental restoration and/or protection, such as afforestation, even if for forest utilization (Gray 2002). The monitoring of the concession system is of the responsibility of governments, which can, however, be given to an NGO or private companies (Søreide 2007).

In the implementation of CSF, the public sector plays, and will continue to play, a central role. Thus, it is important to take into account that the public sector is a political sector where citizens, politicians, and civil servants have a legitimate role as stakeholders in the governing of the state. 


\section{References}

Ackzell L (2010.) Federation of Swedish Family Forest Owners Associations https://www. slideshare.net/CIFOR/federation-of-swedish-family-forest-owners-associations. Accessed 8 Jan 2021

Albrecht M (2012) Governance processes of sustainable forest management: from core markets to resource peripheries. In: M. Avdibegović, G. Buttoud, B. Marić, M. Shannon (Eds.). Assessing Forest Governance in a Context of Change. IUFRO Division 9: Forest Policy and Economics, Research Group 9.05.00 - Forest Policy and Governance. Proceedings of Abstracts from the IUFRO Seminar. 65-66, Sarajevo, Bosnia-Herzegovina, 2012, May, 9-13

Allen MW, Craig CA (2016) Rethinking corporate social responsibility in the age of climate change: a communication perspective. Int J Corp Soc Responsib 1:1

Amdam R (2020) Innovation in public planning. Calculat Commun Innov:33-52. https://doi. org/10.1007/978-3-030-46136-2_3

Arnstein SR (1969) A ladder of citizen participation. JAIP 35:216-224

Armitage DR (2005) Adaptive capacity and community-based natural resource management. Environ Manag 35(6):703-715. https://doi.org/10.1007/s00267-004-0076-z

Aurenhammer PK, Ščap Š, Triplat M, Krajnc N, Breznikar A (2017) Actors' potential for change in Slovenian Forest owner associations. Small-scale Forestry. https://doi.org/10.1007/ s11842-017-9381-2

Baldwin R, Cave M, Lodge M (2011) Understanding regulation: theory, strategy and practice, 2nd edn. Oxford University Press, Oxford

Bastian CT, Keske CMH, McLeod DM, Hoag DL (2017) Landowner and land trust agent preferences for conservation easements: implications for sustainable land uses and landscapes. Landscape and Urban Paknning 157:1-13. https://doi.org/10.1016/j.landurbplan.2016.05.030

Battisti A, Larsson SA, Niemelä P (2015) Climate change and insect pest distribution range. Biology:1-15

Beland Lindahl K, Sandström C, Sténs A (2017) Alternative pathways to sustainability? Comparing forest governance models. Forest Policy Econ 77:69-78. https://doi.org/10.1016/J. FORPOL.2016.10.008

Bennet NJ, Whitty TS, Finkbeiner E, Pittman J, Bassett H, Gelcich S, Allison EH (2018) Environmental stewardship: a conceptual review and analytical framework. Environ Manag 611:597-614

Besseau P, Dansou K, Johnson F (2002) The International Model Forest Network (IMFN): elements of success. For Chron 78(5):648-654

Blicharska M, Angelstam P, Antonson H, Elbakidze M, Axelsson R (2011) Road, forestry and regional planners' work for biodiversity conservation and public participation: a case study in Poland's hotspot regions. J Environ Plan Manag 54(10):1373-1395

Boakye-Danquah J, Reed MG (2019) The participation of non-industrial private forest owners in forest certification programs: the role and effectiveness of intermediary organisations. Forest Policy Econ 100:154-163. https://doi.org/10.1016/j.forpol.2018.12.006

Böocher M (2012) A theoretical framework for explaining the choice of instruments in environmental policy. Forest Policy Econ 16:14-22

Brammer S, Jackson G, Matten D (2012) Corporate social responsibility and institutional theory: new perspectives on private governance. Soc Econ Rev 10:3-28

Braune A, Wittstock B (2011) Measuring environmental sustainability: the use of LCA based building performance indicators. LCM2011: Tools for Green and Sustainable Buildings

Bryson JM, Crosby BC, Bloomberg L (2014) Public value governance: moving beyond traditional public administration and the new public management. Public Adm Rev 74:445-456. https:// doi.org/10.1111/puar.12238

Buergin R (2016) Ecosystem restoration concessions in Indonesia: conflicts and discourses. Crit Asian Stud 48(2):278-301 
Buliga B, Nichiforel L (2019) Voluntary forest certification vs. stringent legal frameworks: Romania as a case study. J Clean Prod 207:329-342

Busenberg GJ (2004) Wildfire Management in the United States: the evolution of a policy failure. Rev Policy Res 21(2):145-156

Carroll AB (1999) Corporate social responsibility: evolution of a definitional construct. Bus Soc 38:268-295

Cashore B, Gale F, Meidinger E, Newsom D (2006) Introduction: forest certification in analytical and historical perspective. In: Cashore G, Meidinger N (eds) Confronting sustainability: forest certification in developing and transitioning countries. Yale Publishing Services Centre, Yale, pp 7-24

Chauvin CH (2012) Systemic tools and actors empowerment: the hold up of territory charters by the forest owning communes in France. In: M. Avdibegović, G. Buttoud, B. Marić, M. Shannon (Eds.). Assessing Forest Governance in a Context of Change. IUFRO Division 9: Forest Policy and Economics, Research Group 9.05.00 - Forest Policy and Governance. Proceedings of Abstracts from the IUFRO Seminar. 45-46, Sarajevo, Bosnia-Herzegovina, 2012, May, 9-13

Churchman CW (1967) Wicked problems. Manag Sci 14(4):B-141-B-142

Colaço R, Simão J (2018) Disclosure of corporate social responsibility in the forestry sector of the Congo Basin. Forest Policy Econ. 2018/07/01 92:136-147

Crow S, Danks C (2010) Why certify? Motivations, outcomes and the importance of facilitating organizations in certification of community-based forestry initiatives. Small-scale Forestry 9:295-211

Elliot C, Schlaepfer R (2001) Understanding forest certification using the advocacy coalition framework. Forest Policy Econ:257-266

FAO (2016) The Global Forest Resources Assessment 2015, Rom, 2nd edition, ISBN 978-92-5-109283-5

FAO (2018) Climate change for forest policy-makers - An approach for integrating climate change into national forest policy in support of sustainable forest management - Version 2.0. FAO Forestry Paper no.181. Rome, 68 pp.

Federal Ministry of Food, Agriculture and Consumer Protection (2011) Forest strategy 2020. Sustainable forest management - an opportunity and challenge for society. BMELV, Germany, Bonn

Fernandes PM, Guiomar N, Mateus P, Oliveira T (2017) On the reactive nature of forest firerelated legislation in Portugal: a comment on Mouraio and Martinho (2016). Land Use Policy 60:12-15

Fraser EDG, Dougill AD, Mabee WE, McAlpine P (2006) Bottom up and top down: analysis of participatory process for sustainability indicator identification as a pathway to community empowerment and sustainable environment management. J Environ Manage 78:114-127

FSC (2015). FSC Principles and criteria for forest stewardship. FSC-STD-01-001 V5-2 EN

Gežík V, Brnkaláková S, Baštáková V, Kluvánková T (2021) Economic and social perspective of climate- smart forestry: incentives for behavioral change to climate- smart practices in the long-term. In: Managing Forest Ecosystems, Vol. 40, Tognetti R, Smith M, Panzacchi P (eds). Climate-Smart Forestry in Mountain Regions. Springer Nature, Switzerland, AG

Gloor PA (2007) Collaborative Innovation Newworks - How to Mint Your COINs? The 2007 International Symposium on Collaborative Technologies and Systems, May 21-25. 2007, Orlando, Florida, USA

Górriz-Mifsud E, Bugalho M, Corradini G, Valbuena P (2018) Chapter 14 - Financial incentives and tools for Mediterranean forests. In: Bourlion N, Garavaglia V, Picard N (eds) State of Mediterranean Forests 2018. Food and Agriculture Organization of the United Nations, Rome and Plan Bleu, Marseille, pp 229-242

Graves RA, Williamson MA, Belote RT, Brandt JS (2019) Quantifying the contribution of conservation easements to large-landscape conservation. Biol Conserv 232:83-96. https://doi. org/10.1016/j.biocon.2019.01.024

Gray JA (2002) Forest concession policies and revenue systems - country experience and policy changes for sustainable tropical forestry (English). World Bank Technical paper no. WTP 522. Forestry series. The World Bank, Washington, D.C. 126 pp. 
Grilli G, Fratini R, Marone E, Sacchelli S (2020) A spatial-based tool for the analysis of payments for forest ecosystem services related to hydrogeological protection. Forest Policy Econ 111(102039): $1-14$

Guan X, Tian G, Tian G (2019) The mediating effect of corporate social responsibility on governance structure and investment efficiency based on PLS-SEM. Ekoloji 28(107):3579-3591

Habermas J (1995) Between facts and norms: contributions to a discourse theory of law and democracy. Polity Press, Cambridge

Hajdúchová I, Mikler C, Giertliová B (2019) Corporate social responsibility in forestry. J For Sci 65(11):423-427

Hall JE, Bonnell B (2004) Social and collaborative forestry: Canadian model forest experience. Canadian Forest Service, Ottawa

Higgins V, Dibden J, Potter C, Moon K, Cocklin C (2014) Payments for ecosystem services, neoliberalisation, and the hybrid governance of land management in Australia. J Rural Stud $36: 463-474$

Ho VM, Bonnell B, Kushalappa CG, Mooney C, Sarasin G, Svensson J, Verbisky R (2014) Governance solutions from the international model forest network. News 56:26-34

Hollberg A, Lützkendorf T, Habert G (2019) Top-down or bottom-up? - how environmental benchmark can support the design process. Build Environ 153:148-157

Holzinger K, Knill C (2004) Marktorientierte Umweltpolitik —ökonomischer Anspruch und politische Wirklichkeit. In: Reinhard, Zintl, Roland, Czada (Eds.), Politik und Markt (=PVS Politische Vierteljahresschrift Sonderheft 34), pp. 232-255

Horton K, Knight H, Galvin KA, Goldstein KA, Herrington J (2017) An evaluation of landowners' conservation easements on their livelihoods and well-being. Biol Conserv 209:62-67. https:// doi.org/10.1016/j.biocon.2017.02.016

IMNF (International Model Forest Network) (2019) 30 years of convening power. Model Forests, Multi-stakeholder Partnerships, and Sustainable Development

IMNF (International Model Forest Network) (2020) Landscapes, partnerships, Sustainability. IMNF Spring Newsletter https://imfn.net/. Accessed 8 Jan 2021

International Organization for Standardization (2010) Guidance on social responsibility. ISO Standard No. 26000. Retrieved from https://www.iso.org/obp/ui/\#iso:std:iso:26000:ed-1:v1:en

Jensen SE, McPherson GR (2008) Living with fire: fire ecology and policy for the twenty-first century. University of California Press, Berkeley and Los Angeles

Kotecký V (2015) Contribution of afforestation subsidies policy to climate change adaptation in the Czech Republic. Land Use Policy 47:112-120. https://doi.org/10.1016/j. landusepol.2015.03.014

Kronholm T (2015). Forest owners' associations in a changing society. Doctoral thesis. Swedish University of Agricultural Sciences, Umeå. Acta Universitatis Agriculturae Sueciae, 102, 65 pp. https://pub.epsilon.slu.se/12729/1/kronholm_t_151022.pdf. Accessed 8 Jan 2021

Landell-Mills N, Ford J (1999) Privatising sustainable forestry: a global review of trends and challenges. Instruments for sustainable private sector forestry series. International Institute for Environment and Development, London, $112 \mathrm{pp}$

LaPierre L (2002) Canada's model forest program. Forest Chronicle 78(5):613-617

Lemos MC, Agrawal A (2006) Environmental governance. Annu Rev Env Resour 31:297-325

Lempiäinen A (2011) CSR in forest industry - case study of reporting and implementation of social responsibility in three international companies. MSc Thesis, University of Helsinki, $86 \mathrm{pp}$

Li Y, Gao L (2019) Corporate social responsibility of forestry companies in China: an analysis of contents, levels, strategies, and determinants. Sustainability 11:4379

Lockwood M (2010) Good governance for terrestrial protected areas: a framework, principles and performance outcomes. J Environ Manage 91(3):754-766

Lovrić M, Martinić I, Lovrić N, Landekić M, Šporčić M (2012) Role of NGO’s in the implementation of the habitats directive. In: Avdibegović M, Buttoud G, Marić B, Shannon M (eds) Assessing Forest Governance in a Context of Change. IUFRO Division 9: Forest Policy and Economics, Research Group 9.05.00 - Forest Policy and Governance. Proceedings of Abstracts from the IUFRO Seminar. 61. Sarajevo, Bosnia-Herzegovina, pp 9-13 
Ma Z, Butler BJ, Kittredge DB, Catanzaro P (2012) Factors associated with landowner involvement in forest conservation programs in the U.S.: implications for policy design and outreach. Land Use Policy 29:53-61

Makundi WR (1997) Global climate change and sustainable forest management - the challenge of monitoring and verification. Mitig Adapt Strat Glob Chang 2:133-155

Maryudi A, Devkota RR, Schusser C, Yufanyi C, Salla M, Aurenhammer H, Rotchanaphatharawit R, Krott M (2012) Back to basics: considerations in evaluating the outcomes of community forestry. Forest Policy Econ 14:1-5

McCarthy S, Matthews A, Riordan B (2003) Economic determinants of private afforestation in the Republic of Ireland. Land Use Policy 20:51-59

McManus P (2009) Environmental regulation. Elsevier Ltd., Sidneat

Mourao PR, Martinho VD (2016) Discussing structural breaks in the Portuguese regulation on forest fires - an economic approach. Land Use Policy 54:160-478

Mourao PR, Martinho VD (2019) Forest fire legislation: reactive or proactive? Ecol Indic 104:137-114

Muradian R, Rival L (2012) Between markets and hierarchies: the challenge of governing ecosystem services. Ecosyst Serv 1:93-100

Niedziałkowski K, Paavola J, Jędrzejewska B (2012) Participation and protected areas governance: the impact of changing influence of local authorities on the conservation of the Białowieża Primeval Forest, Poland. Ecol Soc 17(1):2. https://doi.org/10.5751/ES-04461-170102

Niedziałkowski K, Pietrzyk-Kaszyńska A, Pietruczuk M, Grodzińska-Jurczak M (2015) Assessing participatory and multilevel characteristics of biodiversity and landscape protection legislation: the case of Poland. J Environ Plan Manag 59(10):1891-1911. https://doi.org/10.1080/0964056 8.2015.1100982

Niedziałkowski K, Shkaruaba A (2018) Governance and legitimacy of the forest stewardship council certification in the national contexts - a comparative study of Belarus and Poland. Forest Policy Econ 97:180-188

Olschewski R, Bebi P, Teich M, Wissen Hayek U, Grêt-Regamey A (2012) Avalanche protection by forests - a choice experiment in the Swiss Alps. Forest Policy Econ:19-24. https://doi. org/10.1016/j.forpol.2012.02.016

Osborne SP (2006) The new public governance? Public Manag Rev 8:377-387. https://doi. org/10.1080/14719030600853022

Osborne SP (2010) Delivering public services: time for a new theory? Public Manag Rev 12:1-10. https://doi.org/10.1080/14719030903495232

Osman-Elasha B, Parrotta J, Adger N, Brockhaus M, Colfer CJP, Sohngen B, Dafalla T, Joyce LA, Nkem J, Robledo C (2009) Future socio-economic impacts and vulnerabilities. Chapter 4 in: Seppälä, R., Buck, A. and Katila, P. (Eds.) Adaptation of forests and people to climate change: a global assessment report, 101-122 https://researchgate.net/publication/233951303. Accessed 8 Jan 2021

Ostrom E (1990) Governing the commons: the evolution of institutions for collective action. Cambridge University Press, Cambridge, $280 \mathrm{pp}$

Paavola J, Hubacek K (2013) Ecosystem services, governance, and stakeholder participation: an introduction. Ecol Soc 18(4):42. https://doi.org/10.5751/ES-06019-180442

Pahl-Wostl C (2019) The role of governance modes and meta-governance in the transformation towards sustainable water governance. Environ Sci Policy 91:6-16

Paloniemi R, Apostolopoulou E, Cent J, Bormpoudakis D, Scott A, Grodzińska-Jurczak M, Tzanopoulos J, Koivulehto M, Pietrzyk-Kaszyńska A, Pantis JD (2015) Public participation and environmental justice in biodiversity governance in Finland, Greece, Poland and the UK. Environ Policy Gov 25:330-342. https://doi.org/10.1002/eet.1672

Panwar R, Hansen E (2008) Corporate social responsibility in forestry. Unasylva 230 59:45-48

Parkins JR, Dunn M, Reed MG, Sinclair AJ (2016) Forest governance as neoliberal strategy: a comparative case study of the Model Forest Program in Canada. J Rural Studies 45:270-278

Primmer E, Jokinen P, Blicharska M, Barton DN, Bugter R, Potschin M (2015) Governance of ecosystem services: a framework for empirical analysis. Ecosyst Serv 16:158-166 
Prokofieva I, Gorriz E (2013) Institutional analysis of incentives for the provision of forest goods and services: an assessment of incentive schemes in Catalonia (North-East Spain). Forest Policy Econ 37:104-114. https://doi.org/10.1016/j.forpol.2013.09.005

Rametsteiner E (2009) Governance concepts and their application in forest policy initiatives from global to local levels. Small-scale Forestry 8:143-158. https://doi.org/10.1007/ s11842-009-9078-2

Rametsteiner E, Simula M (2003) Forest certification-an instrument to promote sustainable forest management? J Environ Manage 67:87-98

Reed MS (2008) Stakeholder participation for environmental management: a literature review. Biol Conserv 141:2417-2431

Rittel H, Webber M (2007) Dilemmas in a General Theory of Planning (PDF). Archived from the original (PDF) on 2007-09-30. Retrieved 2020-12-14

Rosenkranz L, Seintsch B, Wippel B, Dieter M (2014) Income losses due to the implementation of the habitats directive in forests - conclusions from a case study in Germany. Forest Policy Econ 38:207-218. https://doi.org/10.1016/j.forpol.2013.10.005

RRI-Tools (2020) RRI-Tools. https://rri-tools.eu. Accessed 14 Dec 2020

Saarikoski H, Ákerman M, Primmer E (2012) The challenge of governance in regional forest planning: an analysis of participatory forest program processes in Finland. Soc Nat Resour 25:667-682

Sandström C (2009) Institutional dimensions of co-management: participation, power, and process. Soc Nat Resour 22(3):230-244

Schmithüsen F, Hirsch F (2010) Geneva timber and forest study paper 26. Private forest ownership in Europe. Geneva, Switzerland: UNECE http://www.unece.org/fleadmin/DAM/timber/ publications/SP-26.pdf

Secco L, Pettenella D (2006) Participatory processes in forest management: the Italian experience in defining and implementing forest certification schemes. Schweiz Z Forstwes 157(10):445-452

Secco L, Pettenella D, Gatto P (2011) Forestry governance and collective learning process in Italy: likelihood or utopia? Forest Policy Econ 13:104-112

Seidl R, Schelhaas MJ, Rammer W, Verkerk PJ (2014) Increasing forest disturbances in Europe and their impact on carbon storage. Nat Clim Chang 4(9):806-810. https://doi.org/10.1038/ nclimate2318

Shingo S (2017) Corporate Social Responsibility Kyoto-Style: Kyoto Model Forest's Approach to Collaborative Forest Management. 14 pp. https://imfn.net/wp-content/uploads/2019/01/ CSR_Kyoto_Eng_final.pdf. Accessed 8 May 2020

Slavíková L, Raška P (2019) This is my land! Privately funded natural water retention measures in the Czech Republic. In: Hartmann T, Slavíková L, McCarthy S (eds) Nature-based flood risk management on private land. Springer. https://doi.org/10.1007/978-3-030-23842-1

Sippel A (2007) Forstliche Nutzung in FFH-Gebieten. Situationsanalyse und Perspektiven. Fachstudie erstellt durch die Forstliche Versuchs- und Forschungsanstalt Baden

Stavins R (1998) Market-based environmental policies. BCSIA Discussion Paper 98-02, ENRP Discussion Paper E-98-02, Kennedy School of Government, Harvard University

Stokken R, Børsen T (2020) Scientific literacy in a digital world. In: Halvorsen LJ, Stokken R, Rogne WM, Erdal IJ (eds) Digital samhandling - Fjordantologien 2020. pp. 15-39

Stupak I, Lattimore B, Titus BD, Smith CT (2011) Criteria and indicators for sustainable forest fuel production and harvesting: a review of current standards for sustainable forest management. Biomass Bioenergy 35:3287-3308

Søreide T (2007) Forest concessions and corruption. U4 ISSUE 3:2007 U4 Anti-Corruption Resource Centre Bergen, Norway, $26 \mathrm{pp}$

Sørensen E (2020) Interactive political leadership. 41-58. https://doi.org/10.1093/ oso/9780198777953.003.0004

Špaček M, Kluvánková T, Louda J, Dubová L (2020) Documentation on strategic workshops (CINA) - collective forest management in Czechia and Slovakia, D4.2 subreport, project InnoForESt GA no. 763899. 43 pp. https://innoforest.eu/repository/d4-2-overview/d4-2-cinareport-innovation-region-slovakia-czech-republik/ Accessed 8 May 2020 
Tegegne YT, Van Brusselen J, Cramm M, Linhares-Juvenal T, Pacheco P, Sabogal C, Tuomasjukka D (2018) Making forest concessions in the tropics work to achieve the 2030 agenda: voluntary guidelines, FAO and EFI. FAO Forestry Paper No. 180, Rome, 128pp

Thatcher A (2015) Defining Human Factors for Sustainable Development. https://www.researchgate.net/publication/273965629. Accessed 10 Dec 2020

Thompson GF (2003) Between hierarchies and markets: the logic and limits of network forms of organization. Oxford University Press

Tietenberg TH, Lewis L (2018) Environmental and natural resource economics, 11th edn. Routledge, New York. ISBN: 978-1-138-63229-5

Torfing J (2018) Collaborative innovation in the public sector: the argument. Public Manag Rev 00:1-11. https://doi.org/10.1080/14719037.2018.1430248

UNECE FAO (2018) Forests and water: valuation and payments for forest ecosystem services. United Nations, Geneva

van der Heijden J (2018) Understanding voluntary program performance: introducing the diffusion network perspective. Regulation \& Governance: 44-62

van Hensbergen B (2016) Forest concessions-past present and future? Food and Agriculture Organization of the United Nations, Rome, $76 \mathrm{pp}$

Vatn A (2010) An institutional analysis of payments for environmental services. Ecol Econ 69:1245-1252

Vidal NG, Kozak RA (2008) Corporate responsibility practices in the forestry sector: definitions and the role of context. J Corporate Citizenship 31:59-75

Vizzari M, Lasserre B, Di Martino P, Marchetti M (2012) Promoting community-based natural resources management in Central Italy. In: M. Avdibegović, G. Buttoud, B. Marić, M. Shannon (Eds.). Assessing Forest Governance in a Context of Change. IUFRO Division 9: Forest Policy and Economics, Research Group 9.05.00 - Forest Policy and Governance. Proceedings of Abstracts from the IUFRO Seminar. 62-63, Sarajevo, Bosnia-Herzegovina, 2012, May, 9-13

WBCSD (2000) Corporate social responsibilities - meeting changing expectations. Geneva, $36 \mathrm{pp}$

Weatherall A, Nabuurs G-J, Velikova V, et al (2021) Defining Climate-Smart Forestry. In: Managing Forest Ecosystems, Vol. 40, Tognetti R, Smith M, Panzacchi P (eds). Climate-Smart Forestry in Mountain Regions. Springer Nature, Switzerland, AG

Weiss G, Slee RW, Ollonqvist P, Petenella D (eds) (2011) Innovation in forestry - territorial and value chain relationships. CABI. ISBN: 978-1-84593-689-1

Winkel G, Kaphengst T, Herbert S, Robaey Z, Rosenkranz L, Sotirov M (2009). EU Policy Options for the Protection of European forests Against Harmful Impacts. Albert-Ludwigs-University Institute of Forest and Environmental Policy, Freiburg \& Ecologic Institute, Berlin (146 pp.)

Wu Z, Shao Y, Feng L (2019) Dynamic evolution model of a collaborative innovation network from the resource perspective and an application considering different government behaviors. Information 10(138): 1-16

Wunder S (2005) Payments for environmental services: some nuts and bolts. Center for International Forestry Research, Jakarta 
Open Access This chapter is licensed under the terms of the Creative Commons Attribution 4.0 International License (http://creativecommons.org/licenses/by/4.0/), which permits use, sharing, adaptation, distribution and reproduction in any medium or format, as long as you give appropriate credit to the original author(s) and the source, provide a link to the Creative Commons license and indicate if changes were made.

The images or other third party material in this chapter are included in the chapter's Creative Commons license, unless indicated otherwise in a credit line to the material. If material is not included in the chapter's Creative Commons license and your intended use is not permitted by statutory regulation or exceeds the permitted use, you will need to obtain permission directly from the copyright holder. 